\title{
Adopting Risk Based Maintenance Strategy of Export Gas Pipeline Using House of Risk: A Proposed Framework
}

\author{
Moko Prijambodo ${ }^{1}$ and Imam Baihaqi ${ }^{2}$ \\ ${ }^{1}$ Department of Technology Management, Institut Teknologi Sepuluh Nopember, Surabaya \\ ${ }^{2}$ Department of Business Management, Institut Teknologi Sepuluh Nopember, Surabaya \\ e-mail: ibaihaqi@mb.its.ac.id
}

\begin{abstract}
SNP-BEM is the biggest buried gas export pipeline belong to PT XYZ and has been operated joinly with PT POMA for duration of 20 years. Until today, this pipe has survived very well from the worst potential failure or risk events such as rupture and leak since all strategic of maintenances are considered as sufficient facing the sources of risk agent, despite still different perceptions are presence among the operators in real application. Nevertheless, following the operation versus times, there is an increasing of potential external threat or risk agents due to the growth of housing, the overlapped operational permit of industrial of non-oil/gas, illegal road crossing which may cause the occurrence of risk events/failures. In 2016, there was a critical incident of the soil movement caused by the excessive load of coal's stock pile nearby ROW and impacted to the pipe movement about 6 meters in horizontal and 2 meters in vertical and may lead to disastrous. Therefore, a more effective maintenance strategy is to be developed to reduce these risks. Combination of Fish Bone diagram (FBD) and House of Risk (HOR) is selected to identify the sources of risk and to develop more effective risk-based maintenance strategy. Based on the assessment, it is identified (twelve) 12 credible risk agents which contributing to pipeline failures/risk events and (eight) 8 proposed preventive actions to reduce the risk. These proposed actions shall be agreed by all operators as a reference for developing risk-based maintenance strategy.
\end{abstract}

Keywords-Pipeline, Maintenance, Risk Event, Risk Agent, Preventive Action.

\section{INTRODUCTION}

$I^{\prime}$ N PT XYZ, 42" gas export from SNP-BEM is the biggest pipeline among the other 2 export lines, 32" CPU-BEM \& 32" NPU-BEM. The total gas transporting through this line about 600 MMSCFD (Millions Standard Cubic Feet per day). This is equal to around 600,000 MMBtu/d (Millions British Thermal Unit/d), where the selling gas price about $5 \$ / M M B t u(J u l y ~ 2020)$, therefore the stake production on this line is about $3 \mathrm{M} \$ / \mathrm{d}$. This huge amount of money is contributing to the development of Republic of Indonesian. Therefore, this line is playing very important role and should be carefully operated and maintained to ensure its integrity \& reliability.

This line is designed with maximum pressure of $90 \mathrm{barg}$, at temperature of $55-60 \mathrm{oC}$. It has very long span from SNP to BEM about $82 \mathrm{~km}$ length, buried below soil surface at $2 \mathrm{mtr}$ depth, across different type of terrain from rural onshore, swampy, river crossing and some road crossings with very dense population and industrial growth at current condition. When it was built in 1998, the surrounding area was quite empty and in accordance to ASME 31.8, the pipeline was classified as class 1 , division 2 . It means that the number of buildings within $1.6 \mathrm{~km}$ length and $300 \mathrm{mts}$ spans of line was below 10 houses with design factor below 0.72 . The lines should be able to operate for duration of 30 years design life, meaning that by design it should be finished by 2028 .

Following the government policy, there is also a scheme of FSA (Facility Sharing Agreement) that required sharing operation with the other oil \& gas operators from UAE \& Italy. This scheme will reduce CAPEX so that reducing government financial expenditure at the end. This line is also operated together with other oil \& gas companies from USA as back up line in the case of any plant up set in their facilities occurred. This sharing operation activity is called as POMA (Pipeline Operation \& Maintenance Agreement). This agreement is posing a potential problem since they have different approach \& methodology to handle the operation.

To ensure integrity \& reliability of the line so that it can be operated at least up to design life, the Pipeline Management System has been implemented since beginning of the operation. Nevertheless, at site operational level, the implementation is very challenging to make it happened, due to some reasons such as:

1. Subjectivity of the decision makers involved because different methodology is being used of each operator,

2. Different responsibility of each operator for the same line

3. The growth of non-oil and gas industrial along row corridor (coal mining, plantation, cement, etc)

4. The population growth causing exponentially housing construction

5. Current low oil price \& epidemic covid19 case leading to very tight budget operation (opex).

Therefore, the appropriate approach should be defined to solve the above challenges. Typical of 42" SNP-BEM aerial view \& battery limit of operatorship between PHM \& POMA indicated as Figure 1, where from SNP to RC\#16 (Dondang) is under PT XZY scope, while downstream RC\#16 up to BEM is under POMA scope.

There was a similar experience in previous research for pipeline system using the same approach of HOR. Suhartono (2016) mentioned in his research that the risk of the oil pipeline is assumed inherent to all section of the line, which in actual condition he risk may be differs. He focused on the probability of failure due to time dependent threat (corrosion), referring only the result of In Line Inspection (ILI or Intelligent Pigging), which in writer opinion, this threat is supposed to be more controllable. He didn't consider the actual situation along the pipeline operation which are 
The $6^{\text {th }}$ International Seminar on Science and Technology (ISST) 2020

July $25^{\text {th }}$ 2020, Institut Teknologi Sepuluh Nopember, Surabaya, Indonesia

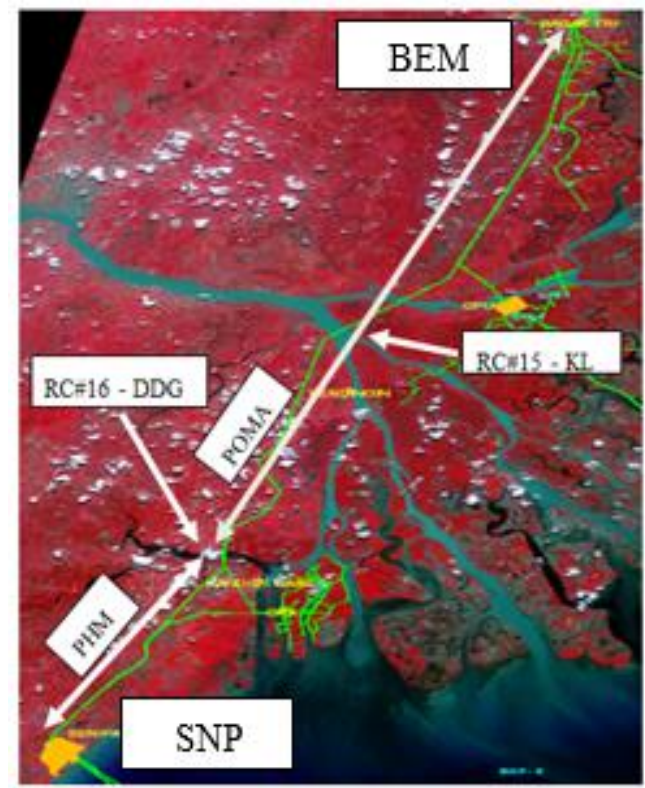

(a)

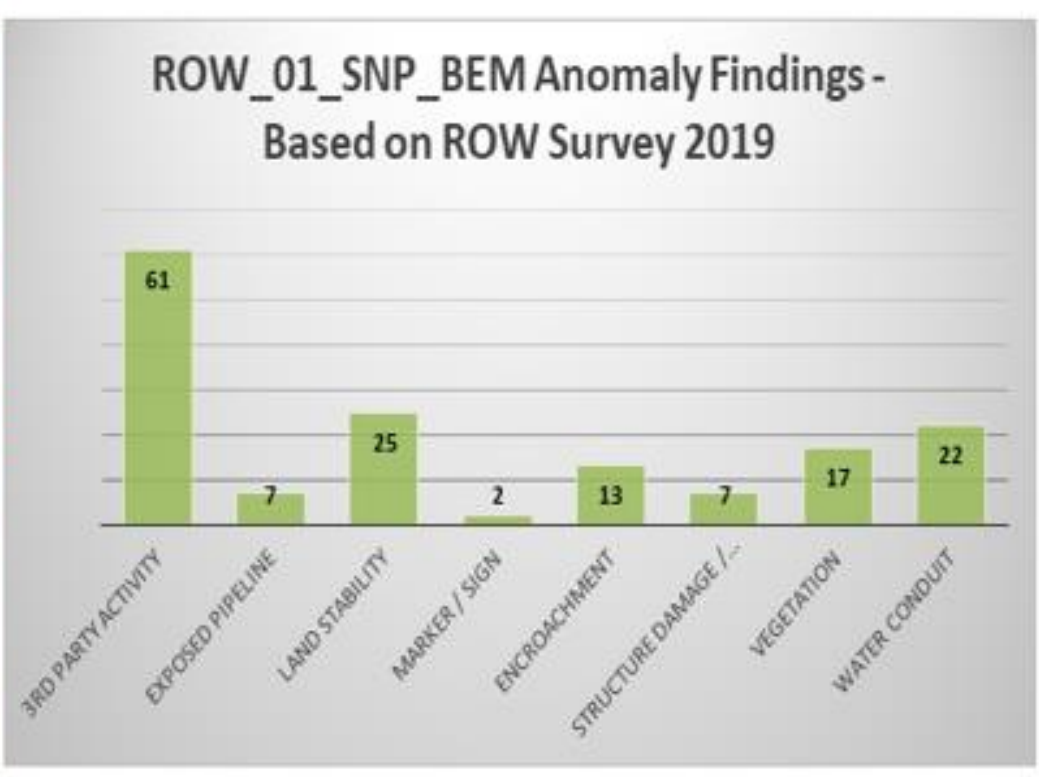

(b)

Figure 1. (a) Battery Limit of Pipeline Maintenance, (b) Anomaly Finding on ROW Survey 2019.

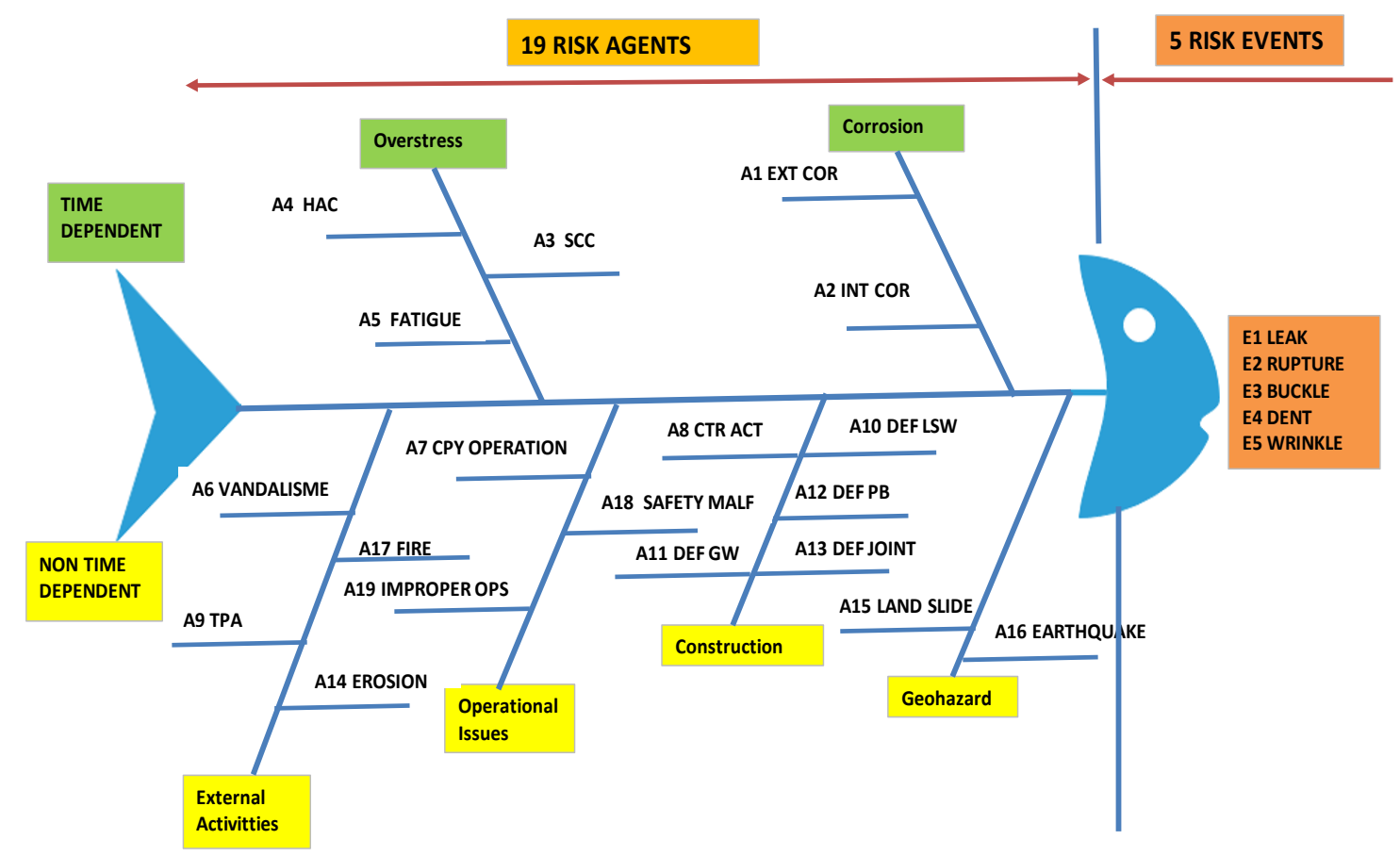

Figure 2. Risk Assessment using Fish Bone Diagram (FBD).

having also a lot of threats due to industrial, population, housing growth which can generated time independent threat and become more uncontrollable if it is not managed very well.

Other researches were also refered, Prasanta Kumar Dey et al (2015), in this study they developed a risk-based maintenance model using a combined multiple-criteria decision-making and weight method (AHP - Anaylitical Hierarchy Process) for offshore oil and gas pipelines in Thailand. The proposed model helps the pipelines operators to analyze the health of pipelines dynamically, to select specific inspection and maintenance method for specific section in line with its probability and severity of failure. However, the opinion of SME (Subject Matter Experts) to provide the feedback is very subjective since they are solely based on their competency \& knowledge on specific site location. Furthermore, there is no specific rule of thumb to be followed in the words to define the appropriate methodology, since the site condition is varied and shall be subject to each pipeline operators.

The research objective will therefore to consider all credible threats either time dependent (internal) and non-time dependent (external), with following detail:

1. To identify the potential pipeline failures (risk events) \& the souce of risks (risk agent).

2. To define the most credible risks to pipeline failures

3. To develop appropriate strategy of pipeline inspection \& maintenance for 42" SNP-BEM. 
The $6^{\text {th }}$ International Seminar on Science and Technology (ISST) 2020

July $25^{\text {th }} 2020$, Institut Teknologi Sepuluh Nopember, Surabaya, Indonesia

Table 1

Nineteen (19) Sources of Risk Agent (A1-A19)

\begin{tabular}{|c|c|c|c|c|c|}
\hline Code & RISK AGENT & Description & Code & RISK AGENT & Description \\
\hline A1 & $\begin{array}{l}\text { External } \\
\text { Corrosion }\end{array}$ & $\begin{array}{l}\text { the deterioration of a material, usually } \\
\text { a metal, that results from an } \\
\text { electrochemical reaction with its } \\
\text { environment (external pipe) }\end{array}$ & A10 & $\begin{array}{l}\text { Defective Long } \\
\text { Seam Weld }\end{array}$ & $\begin{array}{l}\text { Welding defect during pipe } \\
\text { manufacturing normally to the ERW } \\
\text { (Electric Resistance welding) type }\end{array}$ \\
\hline A2 & Internal Corrosion & $\begin{array}{l}\text { the deterioration of a material, usually } \\
\text { a metal, that results from an } \\
\text { electrochemical reaction with its } \\
\text { corrosive fluid (internal pipe) }\end{array}$ & A11 & $\begin{array}{l}\text { Defective Girth } \\
\text { Weld }\end{array}$ & $\begin{array}{l}\text { Welding defect during construction at } \\
\text { pipe joints. }\end{array}$ \\
\hline A3 & $\begin{array}{l}\text { Stress Corrosion } \\
\text { Cracking }\end{array}$ & $\begin{array}{l}\text { a form of environmental attack of the } \\
\text { metal involving an interaction of a } \\
\text { local corrosive environment and tensile } \\
\text { stresses in the metal, } \\
\text { resulting in formation and growth of } \\
\text { cracks. }\end{array}$ & A12 & $\begin{array}{l}\text { Defective Pipe } \\
\text { Body }\end{array}$ & $\begin{array}{l}\text { Metal defect during pipe manufacturing, } \\
\text { transportation or/ and during } \\
\text { construction }\end{array}$ \\
\hline A4 & $\begin{array}{l}\text { Hydrogen-assisted } \\
\text { cracking }\end{array}$ & $\begin{array}{l}\text { Typical defect as A3 above, however } \\
\text { with the presence of hydrogen induced } \\
\text { during welding activities or pipe mill. }\end{array}$ & A13 & $\begin{array}{l}\text { Defective other } \\
\text { joint }\end{array}$ & $\begin{array}{l}\text { Defect which may occurred in the flange } \\
\text { to flange joint connection }\end{array}$ \\
\hline A5 & Fatigue & $\begin{array}{l}\text { fatigue-type cracking of metal caused } \\
\text { by repeated or fluctuating stresses in a } \\
\text { corrosive environment }\end{array}$ & A14 & $\begin{array}{l}\text { Land Wash-out } \\
\text { erosion }\end{array}$ & $\begin{array}{l}\text { Soil erosion which caused by } \\
\text { insufficient water management along } \\
\text { ROW or river current at river crossing }\end{array}$ \\
\hline A6 & $\begin{array}{l}\text { Vandalism/ } \\
\text { Sabotage }\end{array}$ & $\begin{array}{l}\text { The act of certain party by intention to } \\
\text { damage the pipeline system for the } \\
\text { individual benefit }\end{array}$ & A15 & $\begin{array}{l}\text { Slope } \\
\text { movement/land } \\
\text { slide }\end{array}$ & $\begin{array}{l}\text { Soil movement could be due to natural } \\
\text { act or industrial act. }\end{array}$ \\
\hline A7 & $\begin{array}{l}\text { Company } \\
\text { Activity }\end{array}$ & $\begin{array}{l}\text { The repair/maintenance activities } \\
\text { performed by company which may } \\
\text { lead to disturbance of pipeline system }\end{array}$ & A16 & Earthquake & $\begin{array}{l}\text { Natural act which may lead to massive } \\
\text { ground movement and } \\
\text { disaster/catastrophic. }\end{array}$ \\
\hline A8 & $\begin{array}{l}\text { Contractor } \\
\text { Activity }\end{array}$ & $\begin{array}{l}\text { The repair/maintenance activities } \\
\text { performed by contractor which may } \\
\text { lead to disturbance of pipeline system }\end{array}$ & A17 & Fire & $\begin{array}{l}\text { the event where bush or other flammable } \\
\text { product along ROW is burn either by } \\
\text { intention or un intention }\end{array}$ \\
\hline \multirow[t]{2}{*}{ A9 } & \multirow[t]{2}{*}{$\begin{array}{l}\text { Third Party } \\
\text { Activity }\end{array}$} & \multirow[t]{2}{*}{$\begin{array}{l}\text { The act of certain parties beyond } \\
\text { company control which not done by } \\
\text { intention, but it may lead to damage the } \\
\text { pipeline system }\end{array}$} & A18 & $\begin{array}{c}\text { Control/safety } \\
\text { System Malfunction }\end{array}$ & $\begin{array}{l}\text { Malfunctional of the safety system } \\
\text { (GOV - Gas Operated valve, MOV - } \\
\text { Manual Operation Valve, ESDV - } \\
\text { Emergency Shut Down Valve) }\end{array}$ \\
\hline & & & A19 & Improper Operation & $\begin{array}{l}\text { The act of process pipeline operation } \\
\text { beyond the SOP }\end{array}$ \\
\hline
\end{tabular}

Table 2.

Five (5) Risk Events (E1-E5)

\begin{tabular}{cccl}
\hline \hline No & $\begin{array}{c}\text { Risk } \\
\text { Event }\end{array}$ & Code & Description \\
\hline 1 & Leak & E1 & $\begin{array}{l}\text { An unintentional escape of gas from the pipeline, the source of the leak may be holes, cracks (including propagating and } \\
\text { non-propagating, longitudinal, and circumferential), separation or pull-out and loose connections. } \\
\text { A complete failure of any portion of the pipeline } \\
\text { that allows the product to escape to the environment. } \\
\text { Condition in which the pipeline has undergone sufficient plastic deformation to cause permanent wrinkling in the pipe } \\
\text { wall or excessive cross-sectional deformation caused by bending, axial, impact, and/or torsional loads acting alone or in } \\
\text { combination with hydrostatic pressure. } \\
\text { A permanent deformation of the circular cross section } \\
\text { of the pipe that produces a decrease in the diameter and is concave inward. } \\
\text { Pipe bend produced by a field machine or controlled process which may result in prominent contour discontinuities on } \\
\text { the inner radius }\end{array}$ \\
\hline
\end{tabular}

\section{PROPOSED FRAME WORK OF HOR (HOUSE OF RISK)}

The combination House of Risk (HOR) and of Fish Bone Diagram (FBD) is proposed in this study, FBD is used to determine the root cause among possible causes of the main problems. While HOR is used for developing strategy for maintenance by identifying the prevention factors in reducing the probability of failure risk (POF), as well as consequence of failure $(\mathrm{COF})$ due to pipeline failures.

\section{A. Fish Bone Diagram (FBD)}

Fish Bone Diagram (FBD) is initially introduced by Kaoru Ishikawa (1960), who pioneered quality management processes in Kawasaki Shipyard, and in the process became one of the founding fathers of modern management. This
FBD is also knowns as Ishikawa diagrams. The defect/risk events is shown as the fish's head, facing to the right, with the source of causes (risk agent) extending to the left as fishbones; the ribs branch off the backbone for major causes, with sub-branches for root-causes, to as many levels as required.

The fish bone on the left side is then to be categorized into 2 major threats: time dependent and non-time dependent. With refer to literatures \& historical data, the time dependent threat is consisting of corrosion \& overstress, while non time dependent threat is consisting of external activities, operational issues, construction \& geohazard, as described in this Figure 2.

Following this assessment, finally it found 19 sources of risk agents \& 5 risk events. The risk agents are coded as A1A19, while Risk Events are coded with E1-E5. The table of risk agent $\&$ risk event can be found in this Table 1 . 
The $6^{\text {th }}$ International Seminar on Science and Technology (ISST) 2020

July $25^{\text {th }} 2020$, Institut Teknologi Sepuluh Nopember, Surabaya, Indonesia

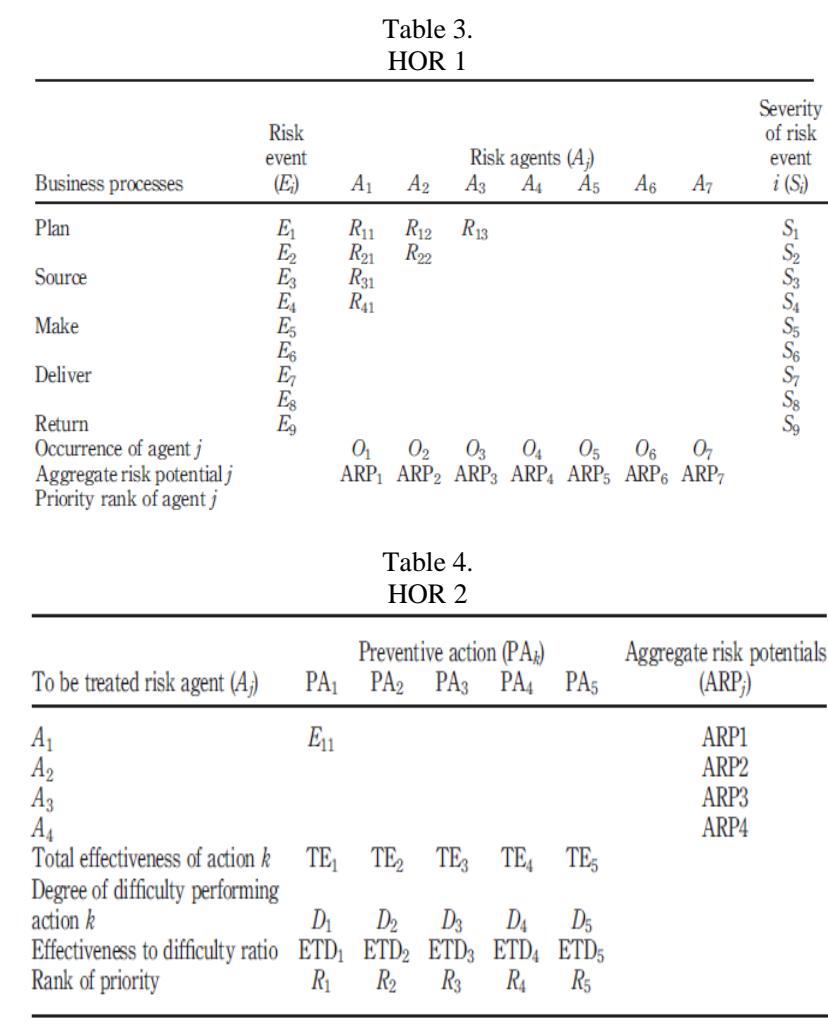

\section{B. House Of Risk (HOR)}

The model is based on the notion that a proactive Supply Chain risk management should attempt to focus on preventive actions, i.e. reducing the probability of risk agents to occur. Reducing occurrence of the risk agents would typically prevent some of the risk events to occur. In such a case, it is necessary to identify the risk events and the associated risk agents. Typically, one risk agent could induce more than one risk events. For example, problems in a supplier production system could result in shortage of materials and increased reject rate where the latter is due to switching procurement to other, less capable, suppliers. The typical process of HOR model can be drawn in Figure 3.

In the well-known FMEA, risk assessment is done through calculation of a RPN as a product of three factors, i.e. probability of occurrence, severity of impacts, and detection. Unlike in the FMEA model where both the probability of occurrence and the degree of severity are associated with the risk events, here we assign the probability to the risk agent and the severity to the risk event. Since one risk agent could induce a number of risk events, it is necessary to quantity the aggregate risk potential of a risk agent. If "Oj" is the probability of occurrence of risk agent " $\mathrm{j}$ ", "Si" is the severity of impact if risk event "i" occurred, and "Rij" is the correlation between risk agent " $\mathrm{j}$ " and risk event "i" (which is interpreted as how likely risk agent $\mathrm{j}$ would induce risk event " $\mathrm{i}$ ") then the "ARPj" (aggregate risk potential of risk agent " $\mathrm{j}$ ") ) can be calculated as follows:

$$
A R P_{j}=O_{j} \sum_{i} S_{i} R_{i j}
$$

The HOQ (House of Quality) model is used to determine which risk agents should be given as the priority for preventive actions. A rank is assigned to each risk agent based

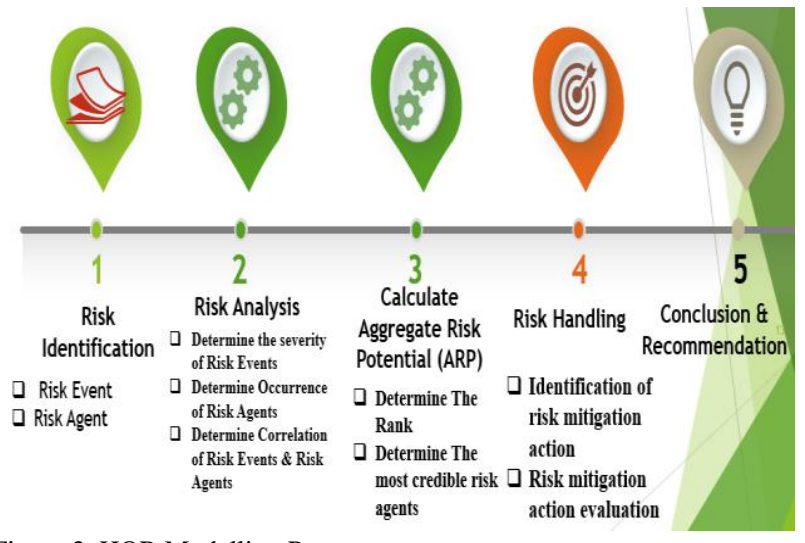

Figure 3. HOR Modelling Processes.

on the magnitude of the ARPj values for each $\mathrm{j}$. Hence, if there are many risk agents, the proposed methodology is to select a few of those considered having large potentials to induce risk events. In this paper, we propose two deployment models, called HOR, both of which are based on the modified HOQ: (1) HOR1 is used to determine which risk agents are to be given priority for preventive actions; (2) HOR2 is to give priority to those actions considered effective but with reasonable money and resource commitments.

\section{1) $\mathrm{HOR} 1$}

In the HOQ model, we relate a set of requirements (what) and a set of responses (how) where each response could address one or more requirements. The degree of correlation is typically classified as none (and given an equivalent value of 0), low (one), moderate (three), and high (nine). Each requirement has a certain gap to fill and each response would require some types of resources and funds. Adopting the above procedure, the HOR1 is developed through the following steps:

1. Identify risk events that could happen in each business process. This can be done through mapping SC processes (such as plan, source, deliver, make, and return) and then identify "what can go wrong" in each of those processes. Ackermann et al. (2007) provide a systematic way of identifying and assessing risks. In HOR 1 model shown in this Table 2-8, the risk events are put in the left column, represented as Ei.

2. Assess the impact (severity) of such risk event (if happened). We use a 1-10 scale where 10 represents extremely severe or catastrophic impact (see Shahin (2004) for a detailed verbal description about the scale).The severity of each risk event is put in the right column of Table 1, indicated as Si.

3. Identify risk agents and assess the likelihood of occurrence of each risk agent. Here, a scale of 1-10 is also applied where 1 means almost never occurred and a value of 10means almost certain to happen.The risk agents (Aj) are placed on top row of the table and the associated occurrence is on the bottom row, notated as $\mathrm{Oj}$.

4. Develop a relationship matrix, i.e. relationship between each risk agent and each risk event, $\operatorname{Rij}\{0,1,3,9\}$ where 0 represents no correlation and 1, 3, and 9 represent, respectively, low, moderate, and high correlations.

5. Calculate the aggregate risk potential of agent $\mathrm{j}(\mathrm{ARPj})$ which is determined as the product of the likelihood of 
Table 5.

HOR 1 - ARP Calculation

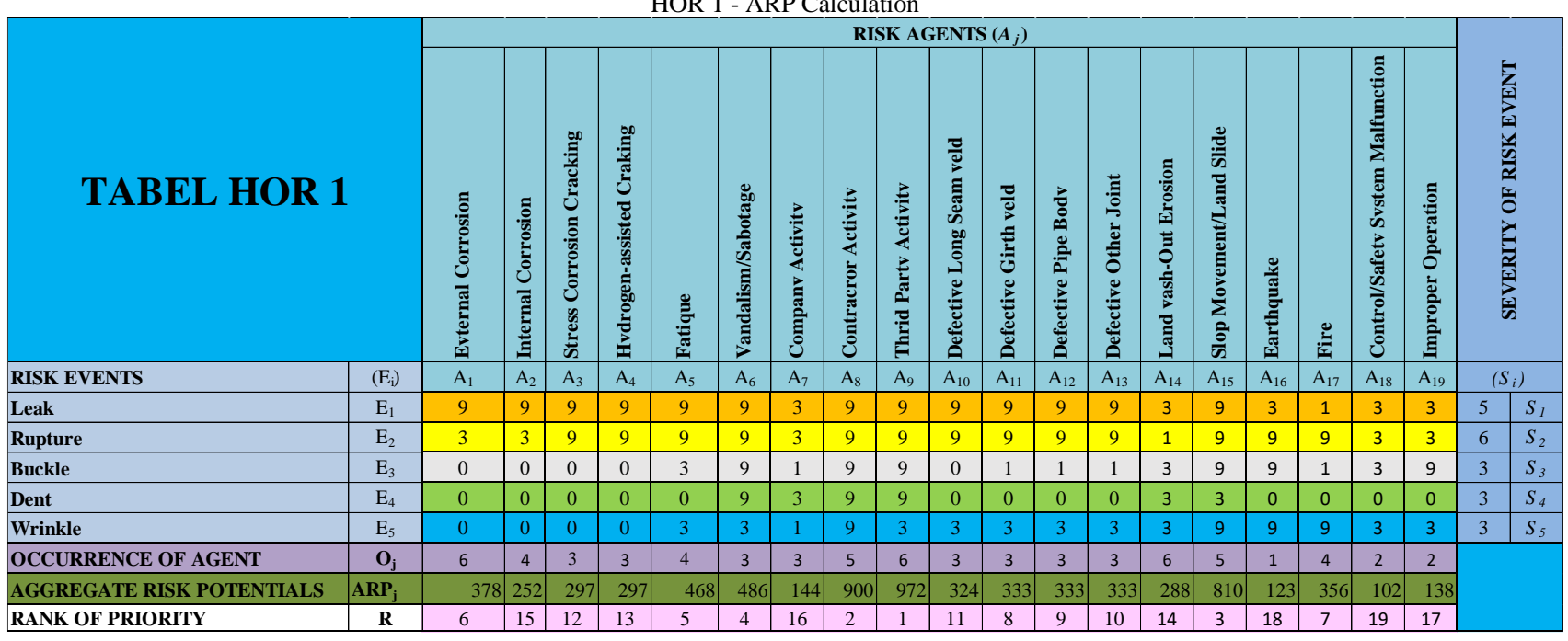

Table 6.

The most 12 credible risk agents

\begin{tabular}{|c|c|c|c|c|c|c|}
\hline \multirow[b]{2}{*}{ RISK AGENTS } & \multicolumn{3}{|l|}{ 11, } & \multirow[b]{2}{*}{$\begin{array}{l}\text { Cumulative } \\
\text { ARP }\end{array}$} & \multirow[b]{2}{*}{ \% Cumulative } & \multirow[b]{2}{*}{ RANK } \\
\hline & Priority & $\mathbf{A R P}_{\mathbf{J}}$ & ARP VALUE & & & \\
\hline Thrid Partv Activity & \multirow{12}{*}{ P1 } & ARP 9 & 972 & 972 & $13 \%$ & $\mathrm{P} 1$ \\
\hline Contracror Activitv & & ARP 8 & 900 & 1872 & $25 \%$ & $\mathrm{P} 2$ \\
\hline Slop Movement/Land Slide & & ARP 15 & 810 & 2682 & $36 \%$ & P3 \\
\hline Vandalism/Sabotage & & ARP 6 & 486 & 3168 & $43 \%$ & P4 \\
\hline Fatique & & ARP 5 & 486 & 3654 & $50 \%$ & P5 \\
\hline Evternal Corrosion & & ARP 1 & 378 & 4032 & $55 \%$ & P6 \\
\hline Fire & & ARP 17 & 356 & 4388 & $60 \%$ & P7 \\
\hline Defective Girth veld & & ARP 11 & 333 & 4721 & $64 \%$ & P8 \\
\hline Defective Pipe Bodv & & ARP 12 & 333 & 5054 & $69 \%$ & P9 \\
\hline Defective Other Joint & & ARP 13 & 333 & 5387 & $73 \%$ & P10 \\
\hline Defective Long Seam veld & & ARP 10 & 324 & 5711 & $78 \%$ & P11 \\
\hline Stress Corrosion Cracking & & ARP 3 & 297 & 6008 & $82 \%$ & P12 \\
\hline Hvdrogen-assisted Craking & \multirow{4}{*}{ P2 } & ARP 4 & 297 & 6305 & $86 \%$ & P13 \\
\hline Land vash-Out Erosion & & ARP 14 & 288 & 6593 & $90 \%$ & P14 \\
\hline Internal Corrosion & & ARP 2 & 252 & 6845 & $93 \%$ & P15 \\
\hline Companv Activitv & & ARP 7 & 144 & 6989 & $95 \%$ & P16 \\
\hline Improper Operation & \multirow{3}{*}{ P3 } & ARP 19 & 138 & 7127 & $97 \%$ & P17 \\
\hline Earthquake & & ARP 16 & 123 & 7250 & $99 \%$ & P18 \\
\hline \multirow[t]{2}{*}{ Control/Safetv Svstem Malfunction } & & ARP 18 & 102 & 7352 & $100 \%$ & P19 \\
\hline & & TOTAL & 7352 & & & \\
\hline
\end{tabular}

occurrence of the risk agent $\mathrm{j}$ and the aggregate impacts generated by the risk events caused by the risk agent $\mathrm{j}$ as in equation (1).

6. Rank risk agents according to their aggregate risk potentials in a descending order (from large to low values).

\section{2) $\mathrm{HOR} 2$}

HOR2 is used to determine which actions are to be done first, considering their differing effectiveness as well as resources involved and the degree of difficulties in performing. The company should ideally select set of actions that are not so difficult to perform but could effectively reduce the probability of risk agents occurring. The steps are as follows: a. Select a number of risk agents with high-priority rank, possibly using Pareto analysis of the ARPj, to be dealt with in the second HOR. Those selected will be placed in the left side (what) of HOR2 as depicted in Table 2. Put the corresponding ARPj values in the right column.

b. Identify actions considered relevant for preventing the risk agents. Note that one risk agent could be tackled with more than one actions and one action could simultaneously reduce the likelihood of occurrence of more than one risk agent. The actions are put on the top row as the "How" for this HOR in Table 4.

c. Determine the relationship between each preventive action and each risk agent, Ejk. The values could be $\{0,1$, $3,9\}$ which represents, respectively, no, low, moderate, and high relationships between action $\mathrm{k}$ and agent $\mathrm{j}$. This 
The $6^{\text {th }}$ International Seminar on Science and Technology (ISST) 2020

July $25^{\text {th }} 2020$, Institut Teknologi Sepuluh Nopember, Surabaya, Indonesia

Table 7.

HOR2- Total Effctivenes of Actions

\begin{tabular}{|c|c|c|c|c|c|c|c|c|c|c|c|c|c|c|c|c|c|c|c|c|c|}
\hline RISK AGENTS & $\left(A_{j}\right)$ & PAl & PA2 & PA3 & PA4 & PA5 & PA6 & PA7 & PA8 & PA9 & PA10 & PAll & PA12 & PA13 & PA14 & PA15 & PA16 & PA17 & PA18 & PA19 & $\mathrm{ARP}_{\mathrm{j}}$ \\
\hline Thrid Partv Activity & A9 & 0 & 0 & 0 & 0 & 0 & 9 & 3 & 3 & 0 & 0 & 3 & 0 & 0 & 0 & 0 & 0 & 9 & 9 & 9 & 1134 \\
\hline Contracror Activity & A8 & 0 & 0 & 0 & 0 & 0 & 9 & 3 & 3 & 0 & 0 & 3 & 0 & 0 & 0 & 0 & 0 & 3 & 9 & 9 & \\
\hline Slop Movement/Land Slide & A15 & 0 & 0 & 0 & 0 & 0 & 9 & 3 & 9 & 0 & 0 & 1 & 9 & 0 & 0 & 0 & 0 & 0 & 0 & 0 & \\
\hline Vandalism/Sabotage & A6 & 0 & 0 & 0 & 0 & 0 & 9 & 3 & 3 & 0 & 0 & 9 & 0 & 0 & 0 & 0 & 0 & 9 & 9 & 1 & \\
\hline Fatique & A5 & 0 & 0 & 0 & 0 & 0 & 0 & 0 & 1 & 9 & 0 & 9 & 0 & 9 & 9 & 0 & 0 & 0 & 0 & 0 & \\
\hline \begin{tabular}{|l} 
Evternal Corrosion \\
\end{tabular} & $\mathrm{Al}$ & 0 & 9 & 9 & 9 & 0 & 3 & 3 & 9 & 0 & 9 & 0 & 0 & 0 & 9 & 0 & 0 & 0 & 0 & 0 & \\
\hline Fire & A17 & 0 & 0 & 0 & 0 & 0 & 9 & 3 & 3 & 0 & 0 & 3 & 0 & 0 & 0 & 0 & 0 & 9 & 9 & 9 & \\
\hline Defective Girth veld & All & 0 & 0 & 0 & 0 & 0 & 0 & 0 & 3 & 0 & 0 & 3 & 0 & 0 & 9 & 0 & 0 & 0 & 0 & 1 & \\
\hline Defective Pipe Bodv & A12 & 0 & 0 & 0 & 0 & 0 & 0 & 0 & 3 & 0 & 0 & 3 & 0 & 0 & 9 & 0 & 0 & 0 & 0 & 1 & \\
\hline Defective Other Joint & A13 & 0 & 0 & 0 & 0 & 0 & 0 & 0 & 3 & 0 & 0 & 3 & 0 & 0 & 1 & 0 & 0 & 0 & 0 & 1 & \\
\hline Defective Long Seam veld & A10 & 0 & 0 & 0 & 0 & 0 & 0 & 0 & 3 & 0 & 0 & 3 & 0 & 0 & 1 & 0 & 0 & 0 & 0 & 1 & \\
\hline Stress Corrosion Cracking & $\mathrm{A} 3$ & 9 & 3 & 9 & 9 & 9 & 0 & 0 & 3 & 9 & 3 & 0 & 0 & 9 & 9 & 0 & 0 & 0 & 0 & 0 & \\
\hline Total Effectiviness of Action $k$ & $\mathrm{TE}_{k}$ & 2673 & 4293 & 6075 & 6075 & 2673 & 34308 & 12192 & 24693 & 7047 & 4293 & 20724 & 7290 & 7047 & 17109 & 0 & 0 & 20484 & 25884 & 23328 & \\
\hline $\begin{array}{l}\text { Degree of Difficulty Performing } \\
\text { Action } k\end{array}$ & $\mathrm{D}_{k}$ & 2 & 3 & 2 & 4 & 3 & 2 & 3 & 3 & 2 & 4 & 3 & 2 & 3 & 4 & 3 & 1 & 2 & 2 & 2 & \\
\hline $\begin{array}{l}\text { Effectiveness to Difficulty Ratio of } \\
\text { Action } k\end{array}$ & $\mathrm{ETD}_{\mathrm{k}}$ & 1337 & 1431 & 3038 & 1519 & 891 & 17154 & 4064 & 8231 & 3524 & 1073 & 6908 & 3645 & 2349 & 4277 & 0 & 0 & 10242 & 12942 & 11664 & \\
\hline Rank of Proactive $k$ & $\mathrm{R}_{\mathrm{R}}$ & 15 & 14 & 11 & 13 & 17 & 1 & 8 & 5 & 10 & 16 & 6 & 9 & 12 & 7 & 18 & 19 & 4 & 2 & 3 & \\
\hline
\end{tabular}

Table 8.

The 8 most Effective Preventive Action

\begin{tabular}{|c|c|c|c|c|c|c|}
\hline PREVENTIVE ACTION & RANK & $\mathrm{PA}_{\mathbf{J}}$ & $\mathbf{E T D}_{k}$ & $\begin{array}{l}\text { Cumulative } \\
\text { ETD }\end{array}$ & \% Cumulative & RANK \\
\hline To perform regular ROW patrol & \multirow{8}{*}{ P1 } & PA6 & 17154 & 17154 & $18 \%$ & P1 \\
\hline $\begin{array}{l}\text { To perform regular education \& socialization to all stakes along ROW, i.e. } \\
\text { vilagers, industrial, and government. }\end{array}$ & & PA18 & 12942 & 30096 & $32 \%$ & P2 \\
\hline To perform regular review \& update of the existing SOP \& operating guidelines. & & PA19 & 11664 & 41760 & $44 \%$ & P3 \\
\hline To perform monitoring \& maintain regularly all Markers (ROW, Pipe), & & PA17 & 10242 & 52002 & $55 \%$ & P4 \\
\hline Reinstate the pipe should any exposed due to erosion, landslide or other causes. & & PA8 & 8231 & 60233 & $64 \%$ & P5 \\
\hline To put appropriate protection at road crossing area & & PA11 & 6908 & 67141 & $71 \%$ & P6 \\
\hline To Cut \& Replace, or to put sleeve the corroded section at wall thickness below & & PA14 & 4277 & 71418 & $76 \%$ & P7 \\
\hline To perform Vegetation Clearing regularly & & PA7 & 4064 & 75482 & $80 \%$ & P8 \\
\hline To install geotextile \& repair of the affected soil eroded area. & \multirow{5}{*}{ P2 } & PA12 & 3645 & 79127 & $84 \%$ & P9 \\
\hline To put sandbag support at free span cases & & PA9 & 3524 & 82651 & $88 \%$ & P10 \\
\hline To perform maintenance $\&$ reading of $\mathrm{CP}$ Potential regularly at test point & & PA3 & 3038 & 85688 & $91 \%$ & P11 \\
\hline Regular monitoring \& to put additional pipe support to minimize vibration. & & PA13 & 2349 & 88037 & $93 \%$ & P12 \\
\hline To perform pipeline liquid coating refurbishment & & PA4 & 1519 & 89556 & $95 \%$ & P13 \\
\hline $\begin{array}{l}\text { To perform adjustment of current } \& \text { voltage at CPTR regularly and to provide } \\
\text { additional sacrificial anodes should the protection level is below the }\end{array}$ & \multirow{8}{*}{ P3 } & & & & & \\
\hline requirements. & & PA2 & 1431 & 90987 & $96 \%$ & P14 \\
\hline Continuously Inject Corrosion Inhibitors to the lines & & PA1 & 1337 & 92324 & $98 \%$ & P15 \\
\hline To perform composite refurbishment should any heavy corrosion external. & & PA10 & 1073 & 93397 & $99 \%$ & P16 \\
\hline To perform cleaning pigging regularly to ensure line cleanliness & & PA5 & 891 & 94288 & $100 \%$ & P17 \\
\hline To maintain pig barrels \& isolation valves regularly & & PA15 & 0 & 94288 & $100 \%$ & P18 \\
\hline To perform regularly function test of safety system ( ESDV, SDV, PSHH, PSLL & & PA16 & 0 & 94288 & $100 \%$ & P19 \\
\hline & & TOTAL & 94288 & & & \\
\hline
\end{tabular}

relationship (Ejk) could be considered as the degree of effectiveness of action $\mathrm{k}$ in reducing the likelihood of occurrence of risk agent $\mathrm{Oj}$.

d. Calculate the total effectiveness of each action as follows:

$$
T E_{k}=\sum_{j} A R P_{j} E_{j k} \quad \forall k
$$

e. Assess the degree of difficulties in performing each action, $\mathrm{Dk}$, and put those values in a row below the total effectiveness. The degree of difficulties, which can be represented by a scale (such as Likert or other scale), should reflect the fund and other resources needed in doing the action.

f. Calculate the total effectiveness to difficulty ratio, i.e. ETDk $1 / 4$ TEk=Dk.

g. Assign rank of priority to each action $(\mathrm{Rk})$ where Rank 1 is given to the action with the highest ETDk.

\section{ADOPTING OF HOR IN DEVELOPING RISK BASED MAINTENANCE STRATEGY OF EXPORT GAS PIPELINE}

Following the result FBD assessment, the questionaire as described in Table 2 and 3 are to be prepared $\&$ sent to respondent for further comment. The selected respondents are taken within company's SME (Subject Matter Experts) from the entities of safety, operation, project and inspection. They are requested to provide their opinion in term of severity \& its correlation. The other questionaires in regard the proposed preventive actions are also given to respondent to know the correlation with the risk agents \& its difficulty level for further site implementation.

Further to these questioanires, the qualified data is obtained based on the modus approach, then to be discussed 
The $6^{\text {th }}$ International Seminar on Science and Technology (ISST) 2020

July $25^{\text {th }} 2020$, Institut Teknologi Sepuluh Nopember, Surabaya, Indonesia

in the FGD (Forum Group Discussion) attended by the SMEs to get the final validation.

From HOR 1, the calculation of ARP (Aggregate Risk Potential) is to be performed as Table 5 and using the Pareto approach, it is found that the first $80 \%$ of cummulative score to be considered as P1 (Priority 1) with 12 most credible source of risk agents, as presented on Table 6 .

While the result of HOR 2 evaluation, following the calculation of Total Effectiveness (TE) in Table 7, finally it is found the (eight) 8 most effective preventive action as presented in Table 8 also using typical prioritization approach of Pareto.

\section{CONCLUSION AND RECOMMENDATION}

Based on the assessment result in previous chapter, it can be concluded that: (a) (Five) 5 risk events have been identified as potential failure to the pipeline, with the highest severity governed by Rupture then followed by leak and 19 risk agents have been identified from FBD assessment, which consist of 2 major threats, namely time dependent threat with 5 sources of risk agent and non-time dependent threat with 14 risk agents; (b) Following assessment of HOR1 (ARP Aggregate Risk Potential), (twelve) 12 risk agents have been defined as credible risk to the failure of export gas pipeline 42" SNP-BEM, using pareto approach; (c) Based on HOR 2 assessment (Effectiveness to Difficulty Ratio), finaly, (eight) 8 preventive actions will be taken as first priority for the proposed maintenance strategy of 42" SNP-BEM export gas pipeline, with the difficulty level within relatively low to medium level from 2 (easy) to 3 (difficult). Some actions will be done in straight forward, such as the first 4 preventive actions, whiles the rest shall be discussed with the authority since some permits \& budget approval to be obtained.

And recommendations: (a) After performing the research, it is recommended to apply FBD \& HOR methodology in maintenance priority to other pipelines within PT XYZ; (b) The proposed preventive actions shall be communicated $\&$ to be agreed by other pipeline operators (POMA) to get the same perception and understanding during site implementation; (c) This thesis scope is not considering detail cost impact and resources limitation.

\section{REFERENCES}

[1] Pujawan, I. N., Geraldin, L. H., (2009), House of Risk: A Model for Proactive Supply Chain Risk Management, Business Process Management Journal, Vol. 15, No. 6, page. 953-967.

[2] Utari, R., Baihaqi, I., (2015), Perancangan Strategi Mitigasi Resiko Supply Chain di PT Atlas Copco Nusantara dengan Metoda House of Risk, Prosiding Seminar Nasional Manajemen Teknologi XXII, Surabaya. Suhartono, "Penetuan Strategi perawatan pipa penyalur untuk mengurangi resiko menggunakan HOR" Institut Teknologi Sepuluh Nopember, 2016,

[3] Dey, Prasantakumar., Ogunlan, Stephen., Naksuksakul, Sittichai (2015), Risk Based Maintenance Model for Offshore Oil \& Gas pipeline : A Case Study, Journal of Quality in Maintenance Engineering, Vol 10.No 3. 2004.pp 169-183

[4] Achilaa, M. E., Muchiri, P. N. and. Ikua, B. W. (2015), Selecting an appropriate maintenance policy for petroleum pipeline system using AHP: A case study/Journal of Sustainable Research in Engineering, Vol. 2 (1) 2015, pg. 17-22

[5] Bungaran, "Determining Repair Priority of flange dissmiliar material findings by using Fuzzy - AHP : A Case study PT MHK", Institu Teknologi Sepuluh Nopember, 2018.

[6] American Society Mechanical Engineer, ASME B31.8S, Managing system Integrity of Gas Pipeline, 2010.

[7] Menteri Pertambangan dan Energi, Keputusan tentang keselamatan kerja pipa penyalur minyak dan gas bumi, Nomor 300.K/38/M.PE,1997. 